\title{
日赤研究班による輸血後 GVHDの全国アンケート結果
}

\author{
1)虎の門病院輸血部 \\ 2)赤十字社中央血液センター \\ 3) 東京大学医学部附属病院輸血部 \\ 高橋 孝喜1) 内田 茂治2) 宮本 正樹2) \\ 赤座 達也 ${ }^{2)}$ 柴田 洋一 ${ }^{3)}$ 十字 猛夫 ${ }^{2)}$ \\ 日本赤十字神「血液製剂による \\ 副作用の防止に関する研究班」
}

はじめに

輸血後移植片対宿主病（graft versus host disease； GVHD）は, 輸血後 $1 ２$ 週経過した頃, 発熱と紅斑 で発症し, 肝機能障害, 下病・下血等が続き，最終的 には骨髄無形成による汎血球減少症の結果, 敗血症等 の重症感染等により死に至る合併症である ${ }^{11}$. 従来よ り免度不全例に対してその免険性が指摘されたが，近 年さらに非免疫不全例に於ける多数の発症が証明さ れ, 大きな問題になっている7 市. 有効な治療法が確立 していない現状では，有用な予防法である，自己血輸 血による同種血輸血の回避, あるいは, 輸血血液の事 前放射線照射を広く行うことが必要である．以上を踏 まえて，本症に対する臨床医師の関心を喚気し，予防 策の実施範囲を検討する目的で, 平成 3 年から, 日本 赤十字社の「血液製剂による副作用の防止に関する研 究班；十字猛夫班長」による, 輸血後 GVHD の全国ア ンヶート調査が行われた. 同調查結果から, 臨床的鑑 別診断と危険因子等について解析したので報告する.

\section{方法}

本症の診断基準（発熱, 紅斑, 下痢, 肝障害, 沉血 球減少症) 及び発症機序の解説等を記したパンフレッ 卜（図 1 3 ) を作成し，年間 1,000 単位以上の血液製 剂を輸血する施設の医師を対象に, アンケートを行っ た．同パンフレットでは，「術後紅皮症」といわれたも のの多くは輸血後 GVHD と考えられること，有効な 治療法が確立していないこと,しかも現在も年間100例 以上が死亡していると推定されること等を強調し, 調 査への協力を求めた。調査内容は, (1) 輸血後 GVHD に関する（同パンフレットを読む前の段階での）意識 調査, (2) 輸血後 GVHD と考えられる症例の実態調 查であった。調査の依頼は, 日本赤十字社血液センター の職員が各医療機関の医師に面接して行った。ささらに, 二次調査として, (2)で回答された症例に関して, 年齢,



図 1

性別, 原疾患, 合併症, 併用薬剂, 輸血時期, 製剂の 種類, 臨床経過, 検査值の推移等, 詳細な臨床経過の 調載を依頼し, 複数の班員で輸血後 GVHD の可能性 を検討した。

輸血後 GVHD の確実例判定の基準として, 上述の 5 つの臨床症状の中, 少なくとも発熱, 紅斑, 汎血球 減少症（特に明らかな顆粒球減少症）があることを絶 対条件とした．貧血や血小板減少は輸血による影響も あって明瞭でないケースも多いが, 顆粒球減少は顕著 で重篤な感染症を併発する例が多い，末た，症状経過 を説明し得る他の原因が考光難いことを，もら一つの 条件として各症例を判定した。 


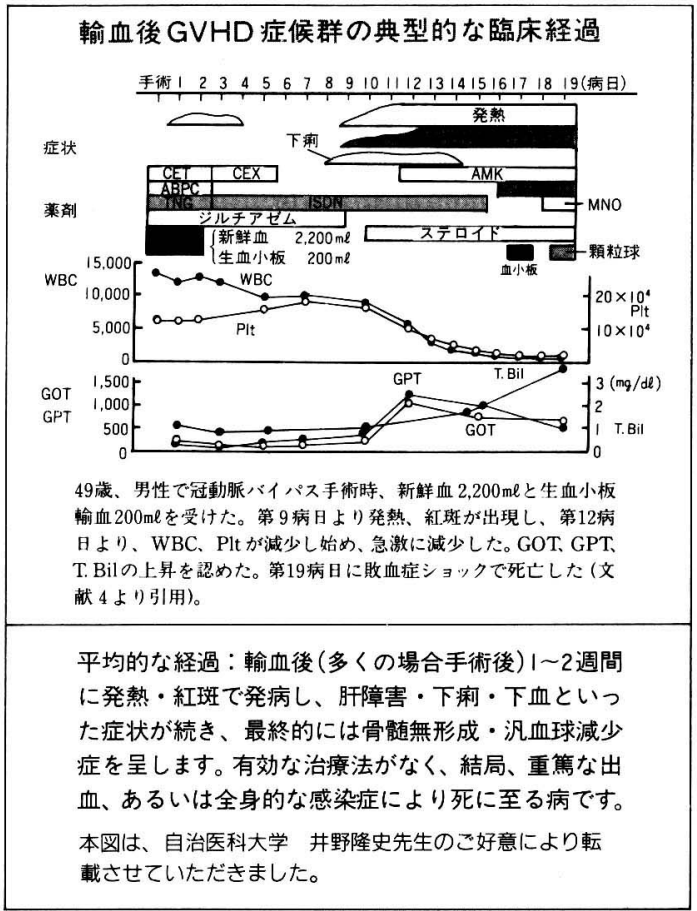

㘠 2 免疫不全でない患者にも発症. 従来は極めて稀 な合併症として，しかも免疫不全の症例にのみ発症 すると考えられてい李したが，現在はごくらつうの 免疫状態の患者さんにも発症することが判明してお り，かなりの方が本症で亡くなられているといわれ ています。

\section{結果}

（1）の輸血後の GVHDの認識に関して，14,083名の

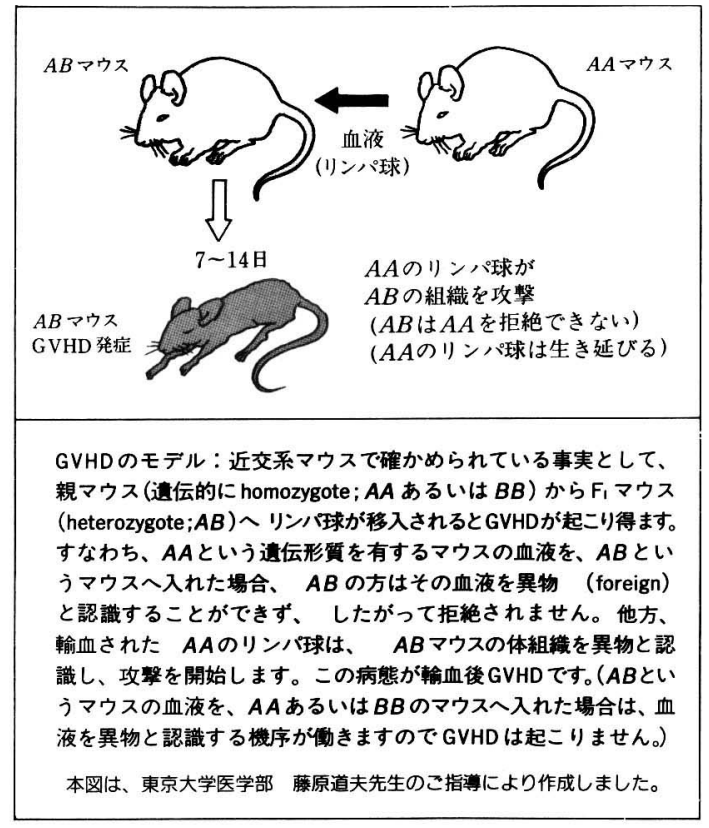

図 3 発症しやすい組合せ，明らかな免疫不全を証明 し得ない患者で, 輸血された血液中のリンパ球を排 除できない場合として, 組織適合性抗原(例えば HLA)が部分的に一致しているケースがあると思わ れます。モデルとして考觉られる近交系マウスの例 を下に示します（図2）。

医師が回答され，「輸血合併症として全く意識されてい なかった」が $28.5 \%$,「免疫不全状態の症例に発症する 稀な合併症と考えていた」が $18.9 \%$ と約半数が「免疫 不全状態にない患者にも本症が発症すること」を十分

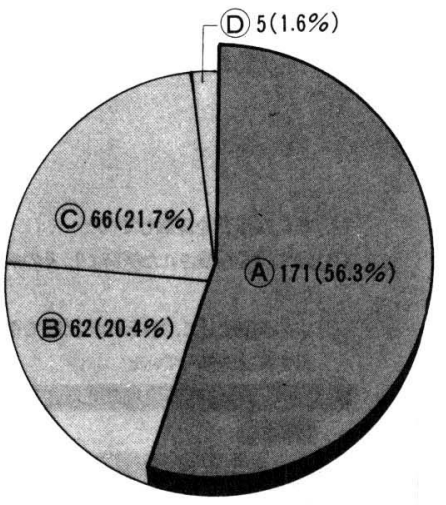

\section{(A)GVHDと刖定された端网}

(B)GVHDか凝われる症例

(C)GVHDとは考之られない症例

(D)詳細なデータの記載がなく、判定できない症例

○304症例のうち.171症例 (56.3\%) が確定例、62例 (20.4\%)が疑い例と考えられました。

図 4 二次調査(総回収症例数304例)における GVHD 判定 
意識されていなかった(図 4).（2）の症例の調査では, 791例の報告をいただき，5つの症状の有無で判断する と，その中 469 例 (59.3\%) が本症に合致すると考えら れた。さらに二次調査により詳細な資料をいただいた 304例の中, 171例（56.3\%）が確実例と判定された。 171 例の性別では男性が $69.6 \%$ と多く, 年齢分布では新 生児例 $(8.2 \%)$ の他，50歳以上が $76.6 \%$ と大半を占め た（図 5 )。背景疾患では，胸部外科 58 例 (33.9\%) の 他, 担癌症例が61例 $(35.7 \%)$ と多く, 外科手術症例 が $80.1 \%$ と圧倒的多数であった(図 6 )。 また，消化性 潰瘍や外傷に際しての輸血例等での発症も認められ た。原因となる輸血に関しては，血縁者間輪血，新鮮 血輸血に起因するものが多く, 特に新生児例では血縁
Japanese Journal of Transfusion Medicine, Vol. 40. No. 3

者からの輸血が大半を占めた(図 7 ). しかし, 保存血, 濃厚赤血球に上る発症も同程度に認め, 採血後 10 日以 上保存した血液による発症例もあった。

\section{考察}

輸血後 GVHD の意識調査に対して，14,000名以上 の医師から回答を得られたことは画期的なことである が，その結果を解析すると，本症に対する関心は必ず しも高くないと思われる. 即ち, 回答の中, 約半数が 〔免疫不全でない症例にも発症し得ること〕を理解され ていなかったこと，そして，意識調査に対する回答率 が約 2 割として, 非回答の医師の関心が回答された医 師より高くないと考觉ると，未だ過半の医師が本症を 深刻に捉えていないおそれがある。予防対策を講ずる

〔男性119例（年齢の記載なし 3 例）、女性45例〕

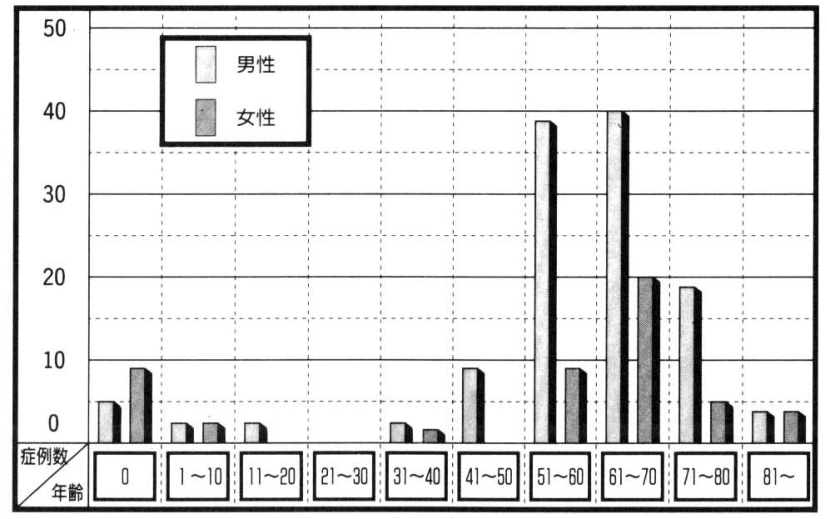

171例のうち、男性が119例 $(69.6 \%)$ を占め、年齢分布では、未熟児新生児の他、比較的 高齢の症例が多いことが確認されました。

図 5 GVHD と判定された症例（171例）の男女別年齢

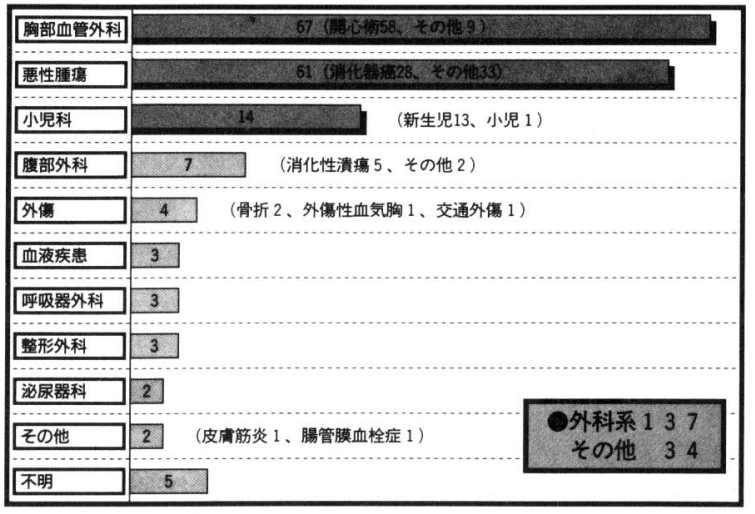

の原疾患につきましては、従来より指摘されていた胸部外科開心術症例が多い他、 特に担癌症例に多く認められました。

図 6 GVHD 症例と判定された171例の原疾患

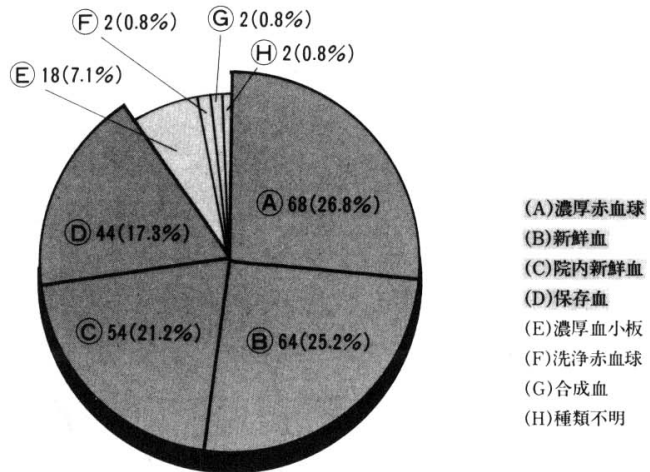

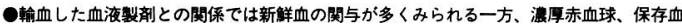
による発症も確認されました。 また院内新鮮血は、とくに小児科における血縁者間の輸血による発症が多くみられます。

図 7 GVHD と判定された症例(171例)の原因と考え られる輸血の相類(重複あり) 
上でも, 本症の実態・危険性を周知させることが重要 と考えられた。

さらに, 輸血後 GVHD の確実例171例のプロフィー ルから, 免疫不全以外に, 男性, 外科手術, 胸部外科症 例，担癌症例，血縁者間輸血等が危険因子と考えられ た.

男女別の年間輪血総単位数は汪ぼ等しく，本調査で 男性例が約70\%を占めたことから，同等の輸血を受け た場合，男性の方が本症をより発症し易いと判断され る。但し，輸血を受けた患者の年跉と輸血量（年跉毎 の輸血総単位数)をみてみると，GVHD 確実例である 171例の年齢分布とよく近似している。したがって，高 齢者の発症が目立つのは輸血機会が多いことを反映し ているに過ぎないと考えられ，高齢は危険因子とはい えない。

背景因子を調べると, 外科手術症例が大半であり, その中でも胸部外科症例, 担癌症例が多くほぼ同数の 症例の報告が認められた。そして，両疾患の輸血総単 位数を比較すると, 胸部血管外科症例は癌患者の約 $1 /$ 3に過ぎないから，同等の輸血を受けた場合，前者が約 3 倍，相対的な危険性は大きいと判断される。胸部血 管外科より相対的には少ないが，癌患者にも一定数本 症が発症していることは重大である，現在，血液製剂 の事前放射線照射に対する保険適応は, 免疫不全患者, $1,500 \mathrm{~g}$ 以下の新生未熟児, 成人の開心術患者等にのみ 認められているが，今後癌患者に対しても（特に手術 の際), 適応拡大が必要である.

血縁者間輸血に起因する GVHD が，特に新生児例 の交換輸血では大半を占め, 血縁者間輸血の危険性が あらためて示された。これに関連して，患者と供血者 の組織適合性抗原の組合わせが一方向性に適合性があ る場合 (one-way matching)，GVHD を発症し易いと 考えられる，即ち，ある組織適合性抗原を重複して有 する保血者 (homozygote) から，その抗原を一つだけ 持つ患者 (heterozygote) への輸血が危険と指摘され てきた（図 3 )。我々は，一般の非血縁者間の輸血（日 赤血の輸血）に比へ，血縁者間の輸血でそうした組合 わせに数倍になり易いと報告してきだ． 今回の調査 で新生児に於ける交換輸血による GVHD 症例の中 で，血縁者（その多くは児の父親）からの輸血例が半 数以上にのぼったことは, 本症の発症に one-way matching が大きく関与していることをあらためて示する のである，絶対的な予防策ではないが，少なくとも血 縁者間輸血を極力避けることが肝要と考えられた。
他方, 保存血, 濃厚赤血球による発症例も, 新鮮血, 院内新鮮血と同程度に認め, 採血後 10 日以上保存した 血液による発症例もあったことから，新鮮血を避ける ことだけでは充分たる対策に成り得ないことが確認さ れた。

\section{結 語}

全国アンケート調查結果から，危険因子等について 考察した。現在，〔血液製剤に対する事前放射線照射〕 を，日赤血液センターが一部代行することが予定され ている。しかし，現状では，本症に対する関心はなお 一般的ではない，予防法を普及させる為には，輸血を 使う全ての医師に本症の危険性を十分認識していただ くことが前提と思われた。

今回の調查で確実な輸血後 GVHD 例と判定された 171例のプロフィールから, 免度不全以外に, 男性, 外 科手術, 胸部外科症例, 担癌症例, 血縁者間輸血等が 危険因子と考兄られた。特に，担癌症例が多いことが はじめて明らかになり，予防範囲を検討する際に重要 と考えられた。厚生省・日本赤十字社の適切な指導・ 援助により, 予防策が広く行われ, 本症が過去の輸血 副作用になる日が近いことが望まれる。

\section{文献}

1）井野隆史, 松浦昭雄, 高梨利一郎, 榊原高之, 井手 博文, 田所憲治, 村中正治, 森 茂郎, 幸道秀樹： 手術時の輸血による GVHD 様症候群。外科, 00(48) : 706-712,1986-7.

2）青木泰子, 中村治雄, 榊原 謙：腹部大動脈瘤手術 後の輸血による移植片対宿主反応が疑われた高齢 者の 1 例. 日内会誌, $73: 1209-1216,1984$.

3) Sakakibara, T. and Juji, T.: Post-transfusion graft versus host disease after open heart surgery. Lancet, II : 1099, 1986.

4) Matsushita, H., Shibata, Y., Fuse, K. and Kimura, M.: Sex chromatin analysis of lymphocytes involving host organs in transfusion association graft-versus-host disease. Virchows Arch B, 55: 237-239, 1988.

5) Ito, K., Yoshida, H., Yanagibashi, K., et al. : Change of HLA phenotype in postoperative erythroderma. Lancet, I : 413-414, 1988.

6) Juji, T., Talahashi K., Shibata, Y., Ide, H., Sakakibara, T., Ino, T. and Mori, S.: Posttransfusion graft-versus-host disease in immunocompetent patients after cardiac surgery in Japan. N. Engl. J. Med., 321 : 56, 1989.

7) Takahashi, K., Juji, T. and Miyazaki, H. : Post-transfusion graftversus-host disease occurring in non-immunosuppressed patients in Japan. Transfusion Science, 12 : 281-289, 1991. 